\title{
Comparative Study of Housing Loan of HDFC and Allahabad Bank
}

\author{
Anju Otwani \\ Assistant Professor, Rajeev Gandhi College of Computer Application \& Technology Satna (M.P.)
}

\begin{abstract}
:
I. Introduction

shelter is a basic human need and productive investment. Home loan means a sum of money borrowed from a financial Institution or Bank to purchase a house. Home loan consists of an adjustable or fixed rate payment terms. As most of the people don't have the cash funds to pay for a home, outright they can apply for a home loan which will pay the upfront costs for the home also which will have to be paid back monthly over a specified period of time. Without home loans most of the people could not afford to buy a home. According to National Association of Home Builders, the housing industry as a whole contributes about $17 \%$ to $18 \%$ of the nation's GDP. The most common purpose of a home loan is to provide funds to a buyer who needs to purchase a home. Home Equity loans allow a home owner to borrow against the difference between the home's value and the current loan balance.
\end{abstract}

The prime objectives of the study are:

\section{Research Objectives}

- To undertake the comparative analysis of public \& private banks(Allahabad bank and HDFC bank) in housing loan sector.

- To study consumer preference for the above two mentioned banks.

- To analyze the satisfaction level of public and private bank (Allahabad \& HDFC banks home loan customers.

- To know the strength of the Allahabad bank \& HDFC brand.

- To identify the popular schemes of the above two mentioned banks

- To evaluate the impact of tax considerations on housing finance with respect to Allahabad \& HDFC bank.

\section{Research Methodology}

Proposed study is an empirical one and is based on Primary as well as secondary data.

Collection of Primary Data:

The primary data for my study was being collected by conducting survey among 100 people through Questionnaires and telephonic Interview. Primary data also included information collected by personal interview with the Managers of Allahabad Bank and HDFC Bank.

\section{Collection of Secondary Data:}

The sources of secondary data include Annual Reports, Manual, Research papers on Housing loan, Websites and official records of Allahabad Bank and HDFC bank.

Sample Techniques:

The sample was selected using a convenient sampling.

Execution of Survey work:

I have done survey work to collect primary and secondary data. I personally approached to individuals and got the questionnaires filled $\mathrm{b} y$ them. Selection of individuals was random.

\section{System of Research Methodology:}

Survey research

Research Instrument

Contact Method

Sampling Unit

Sampling

Sampling size
It was a Descriptive research

Questionnaires

Personal Interview

Customers

Random

sample size for this project was 100 respondents. 


\section{Data Analysis and Interpretation}

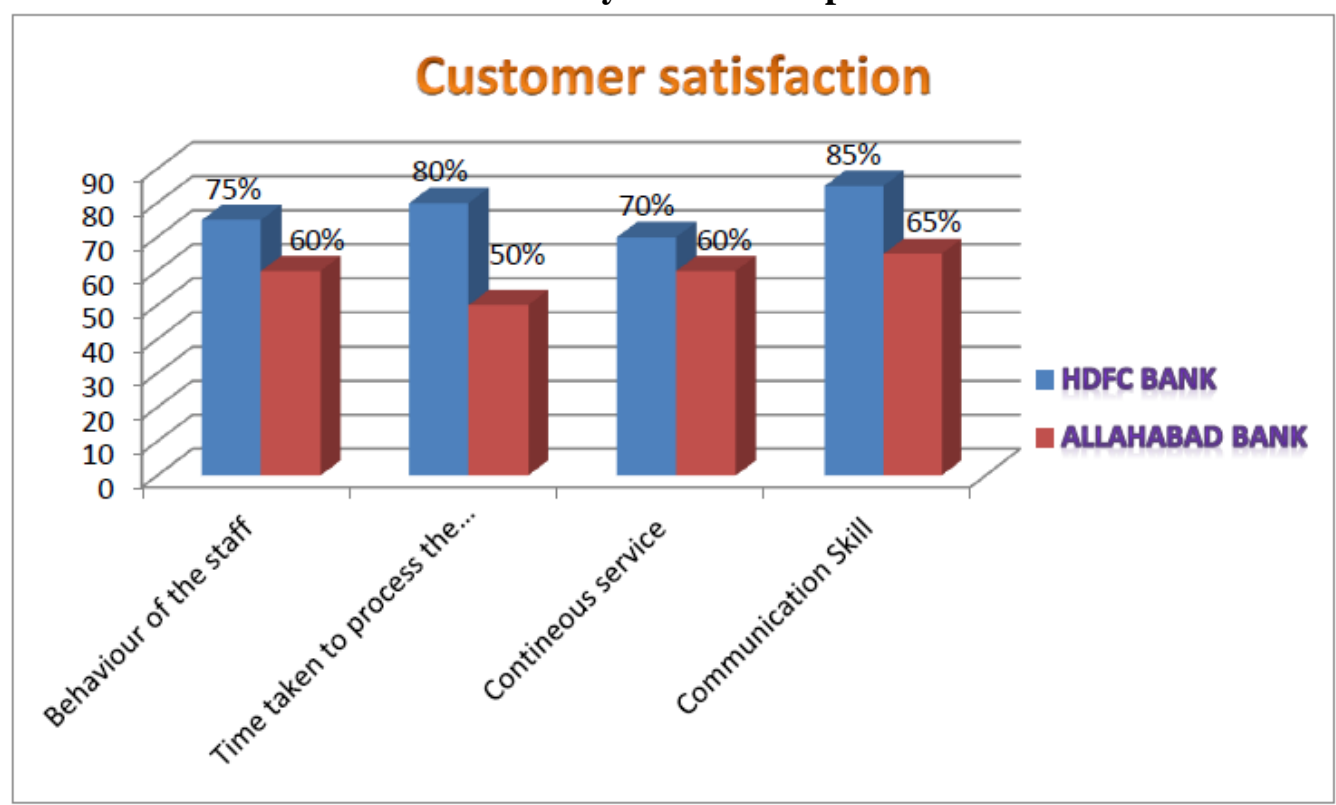

The above analysis denotes the customer satisfaction ratio under the following Heads:

\begin{tabular}{|l|l|l|l|l|}
\hline S.No & \multicolumn{2}{|c|}{ HDFC Bank } & $\begin{array}{l}\text { Allahabad } \\
\text { Bank }\end{array}$ & Remark \\
\hline 1 & Bahaviour of the staff & $75 \%$ & $60 \%$ & $\begin{array}{l}\text { Here the ratio defers } \\
15 \%\end{array}$ \\
\hline 2 & Time taken to process & $80 \%$ & $50 \%$ & $\begin{array}{l}\text { Here the ratio defers } \\
30 \%\end{array}$ \\
\hline 3 & Contineous service & $70 \%$ & $60 \%$ & $\begin{array}{l}\text { Here the ratio defers } \\
10 \%\end{array}$ \\
\hline 4 & Communication Skill & $85 \%$ & $65 \%$ & $\begin{array}{l}\text { Here the ratio defers } \\
20 \%\end{array}$ \\
\hline
\end{tabular}

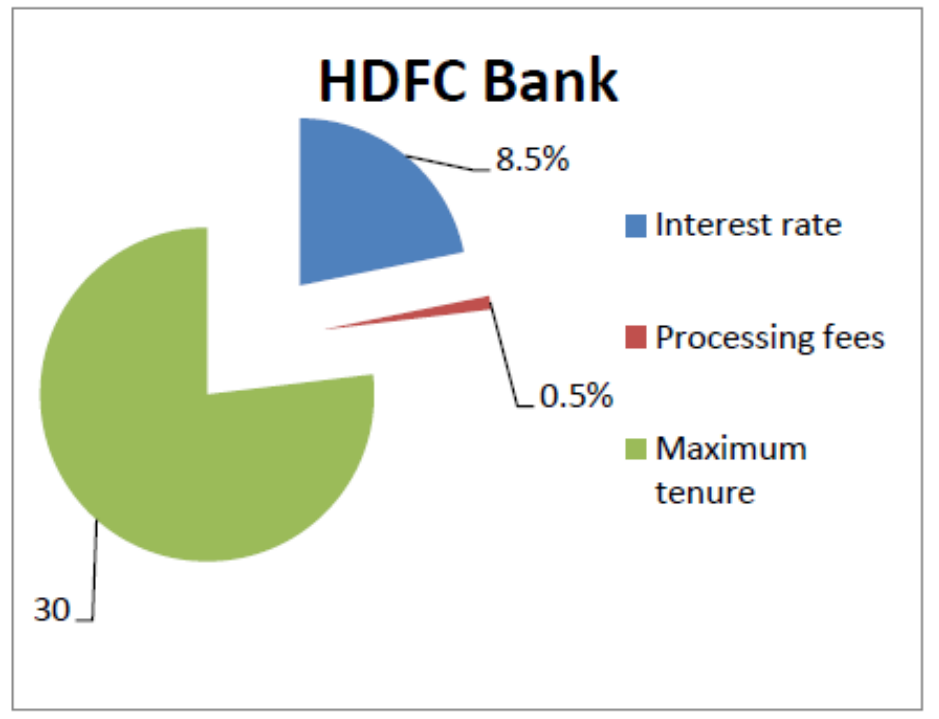




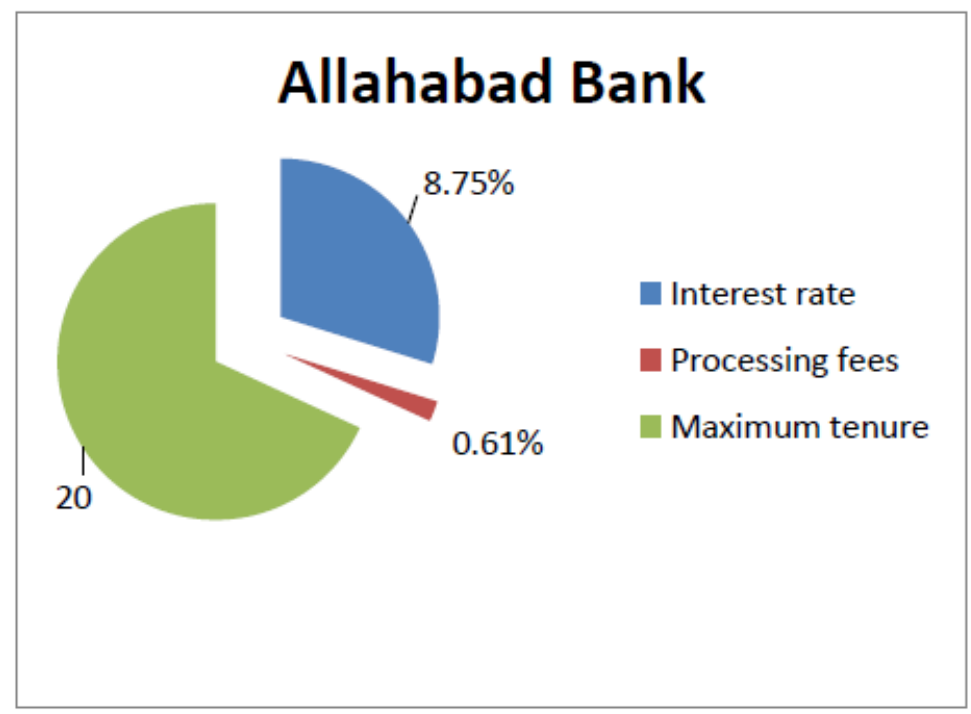

These leading banks develop and innovate various ideas into customer satisfaction goal Here by if we differentiate their interest rates and other factors to understand their process into Housing loans we can summarize the data as follows:

$$
\text { HDFC Bank Allahabad Bank }
$$

$\begin{array}{lll}\text { 1. Interest rate } & 8.50 \% \text { to } 8.55 \% & 8.75 \% \text { to } 9.25 \% \\ \text { 2. Processing Fee } & 0.50 \% & 0.61 \% \\ & \text { (Maximum 11500/-) } & \\ \text { 3. Maximum Tenure } & 30 \text { Years } & 20 \text { Years }\end{array}$

\section{Findings}

- Quality of service like behaviour and time taken to process is very much important criteria which as seen by people before taking home loan.

- According to my survey, respondents are satisfied from the bank where they taking the home loan.

- People get knowledge about home loans from Television, Internet etc.

- According to my survey, interest rates on home loan of HDFC Bank are lower than Allahabad Bank.

- According to my study, loan procedure of HDFC is easy than Allahabad Bank.

- According to my survey maximum people say that hidden charges are taken by private banks.

- Processing fee of HDFC Bank is lower as compare to Allahabad Bank.

- According to my survey, tenure of home loan affects in their selection.

- According to my survey maximum respondents grade HDFC loan procedure as excellent.

- According to my survey maximum respondents grade HDFC loan procedure as good.

\section{Suggestions}

- The staff should be trained to deal with the customers.

- Staff should be friendly and approachable .

- To introduce plans for the low- income group.

- Bank should review the housing loan portfolio at periodical intervals for capturing the new market to avoid isk and for updating their schemes.

- Branches can arrange customers meeting to popularize their loan schemes.

- Attractive incentives should be given to borrowers.

- Forms of loan application should be simplified.

- All information regarding housing loan should be available on the website.

- Reduce rate of interest based on the credit rating should be introduced. 


\section{Limitations}

- This research study was time bound.

- This research study was taken in a limited area only.

- While analysis of data, some human errors could have been possible.

- The sample size is small due to the specified reasons.

- Respondents may give biased answers for the required data. Some of the respondents didn't like to respond.

\section{Conclusions}

On the basis of data analysis and preparation, I would notify that people prefer HDFC Bank more to Allahabad Bank. Youngsters prefer private banks because of the services and facilities offered by them . Customer satisfaction becomes the most differentiating factor for housing loan.

\section{References}

[1]. Mongia, J.N., Housing in India , Neera Enterprises, New Delhi 1982

[2]. Praveen Gupta 2005, Housing finance companies.

[3]. P.S.N. Rao, 1998 Transformation of housing policy in India .

[4]. Jay sampath 2006, Tackling rising home loan rules- Dalal street, Vol XXVII, No. 21 June 2006, PP 89-91

[5]. www.allahabadbank.in

[6]. www.hdfcbank.co.in 